\title{
Arendt Re-defines "the Political" in Turkey: A Theoretical Analysis of the Gezi Protests
}

\author{
Senem Yildirim*
}

In Turkish political culture, the political is usually associated with partisanship and manipulation. With regard to this, current political developments in Turkey show that both government officials and the opposition are embroiled in a constant battle of defining politics and how to be political to the public. This paper takes the Gezi Park protests in Turkey as a case study that illustrates the mentioned negative conceptions of being political. In the initial phase of these protests, even though the protesters and government officials were on opposing sides in this context, they comprehended "the political" from the same perspective. As a reply to this stance, the paper takes an Arendtian approach and argues that the Gezi protests epitomize political action for the very reasons employed to reject their political character. [Article copies available for a fee from The Transformative Studies Institute. E-mail address: journal@transformativestudies.org Website: http://www.transformativestudies.org (C2016 by The Transformative Studies Institute. All rights reserved.]

KEYWORDS: Hannah Arendt, Gezi Park Protests, The Political, Public Sphere, Action, Violence.

\section{INTRODUCTION}

\footnotetext{
* Senem Yildirim, Ph.D., is an Assistant Professor in the department of Political Science at Ipek University, Turkey. Her main areas of interest are contemporary political theory, social theory and civil society studies. She is the author of 'Arendt's Promise to Civil Society: Bridging the Social and the Political' (2014) The European Legacy: Toward New Paradigm 19 (7): 869-882; 'Anti-Political Experiences of Women in Local Politics in Turkey: An Arendtian Perspective' (2013) Academic Journal of Interdisciplinary Studies, 2 (8): 535-542. and co-author with Metin Heper of 'Revisiting Civil Society in Turkey' (2011) Southeast European and Black Sea Studies 11 (1): 1-18.

Acknowledgements: An earlier version of this paper was presented in the "Arendt and Revolutionary Politics" panel at the $72^{\text {nd }}$ Annual Midwest Political Science Association Conference (April 2014). Address correspondence to: Senem Yildirim, Department of Political Science, Ipek University, 06550, Ankara, Turkey; e-mail: senemyildirimozdem@gmail.com.
} 